\title{
East Asian Monsoon
}




\title{
WORLD SCIENTIFIC SERIES ON METEOROLOGY OF EAST ASIA
}

\section{Editorial Board}

C.-P. Chang, Naval Postgraduate School (Chair)

George Tai-Jen Chen, National Taiwan University

Yihui Ding, National Climate Center of China

In-Sik Kang, Seoul National University

Ngar-Cheung Gabriel Lau, Princeton University

William K. M. Lau, NASA Goddard Space Flight Center

Akimasa Sumi, University of Tokyo

Bing Wang, University of Hawaii

Guoxiong Wu, Chinese Academy of Sciences

Michio Yanai, University of California, Los Angeles

Tetsuzo Yasunari, Nagoya University

\author{
Vol. 1: East Asia and Western Pacific Meteorology and Climate: \\ Selected Papers of the Fourth Conference \\ edited by C.-P. Chang, Guoxiong Wu, Ben Jou \& C. Y. Lam \\ Vol. 2: East Asian Monsoon \\ edited by C.-P. Chang \\ Vol. 3: Observation, Theory, and Modeling of Atmospheric Variability \\ Selected Papers of Nanjing Institute of Meteorology Alumni in \\ Commemoration of Professor Jijia Zhang \\ edited by Xun Zhu, Xiaofan Li, Ming Cai, Shuntai Zhou, \\ Yuejian Zhu, Fei-Fei Jin, Xiaolei Zou \& Minghua Zhang
}




\section{Vol. 2}

\section{East Asian Monsoon}

edited by

C.-P. Chang

Naval Postgraduate School,

Monterey, California, USA 


\section{Published by}

World Scientific Publishing Co. Pte. Ltd.

5 Toh Tuck Link, Singapore 596224

USA office: 27 Warren Street, Suite 401-402, Hackensack, NJ 07601

UK office: 57 Shelton Street, Covent Garden, London WC2H 9HE

\section{British Library Cataloguing-in-Publication Data}

A catalogue record for this book is available from the British Library.

\section{EAST ASIAN MONSOON}

Copyright (C) 2004 by World Scientific Publishing Co. Pte. Ltd.

All rights reserved. This book, or parts thereof, may not be reproduced in any form or by any means, electronic or mechanical, including photocopying, recording or any information storage and retrieval system now known or to be invented, without written permission from the Publisher.

For photocopying of material in this volume, please pay a copying fee through the Copyright Clearance Center, Inc., 222 Rosewood Drive, Danvers, MA 01923, USA. In this case permission to photocopy is not required from the publisher.

ISBN $981-238-769-2$ 


\section{PREFACE}

The term "Asian summer monsoon" most frequently refers to the heavy summer rainfall season in South Asia, particularly around India. To some in the western world, "East Asian summer monsoon" is a less familiar term. This is partly because seasonal mean maps have a large area of high rainfall in South Asia during boreal summer, while rainfall over a comparably sized area in East Asia is significantly lower. In fact, the East Asian summer monsoon has complex space and time structures that are distinct from the South Asian summer monsoon. It covers both subtropics and midlatitudes and its rainfall tends to be concentrated in elongated rain belts that stretch for many thousands of kilometers and affect China, Japan, Korea, and the surrounding seas. The narrow meridional scale and the tendency of alternating stationary and northward progression stages make the seasonal averaged rainfall in East Asia less concentrated than in South Asia. However, the impacts of floods and droughts on human lives and economics during to East Asian summer monsoon are just as great because the finer intraseasonal space-time structure, coupled with the narrow rivers, is more sensitive to interannual variations. For example, a flood event can result from heavier-than-normal rainfall during the normal subseasonal rain period or from sustained rainfall outside of the normal period or both.

The East Asian summer monsoon is also closely linked with the West Pacific summer monsoon. Both are part of the global climate system and are affected by El Nino - Southern Oscillation (ENSO) and surface temperature variations in the western Pacific and surrounding oceans, the tropospheric biennial oscillation, and the South Asian summer monsoon. In addition, typhoons in the western North Pacific are most active during the East Asian summer monsoon. They may be considered a component of the East Asian summer monsoon as they contribute substantial amounts of rainfall and have major impacts on the region.

The East Asian winter monsoon, or "Asian winter monsoon", may be a more familiar weather system to the western world. Its circulation encompasses a very large meridional domain. Cold air outbreaks emanate from the Siberian high and penetrate deeply into the equatorial region, where the center of maximum rainfall is found in the Maritime Continent region. This center has long been recognized as a major planetary scale heat source that provides a significant amount of the energy that drives the global circulation during boreal winter. The East Asian winter monsoon is directly connected with the Australian summer monsoon by vigorous circulations extending across the equator, and both are affected by ENSO and other oscillations in the Pacific and Indian Ocean. In addition, a number of global teleconnections associated with the East Asian winter monsoon have recently been found. These include a correlation of temperature and precipitation anomalies over North America with fluctuations in the East Asian jet stream, and an association of winter storm development as far away as Europe with precursor convection over the Maritime Continent. 
Because of its impacts on nearly one third of the world population and on the global climate system including effects on climate change, the study of East Asian monsoon has received increased attention in both East Asian countries and in the United States. This book presents reviews of the recent research on the subject. The book is organized into five parts with three chapters each: East Asian summer and winter monsoon, interannual variations, general circulation modeling, synoptic and mesoscale processes, and interactions with other circulations.

The idea of this book originated when the World Meteorological Organization/ Commission on Atmospheric Science Working Group on Tropical Meteorology Research, under the past chair, Dr. Greg Holland, and the present chair, Prof. Lianshou Chen, organized the International Panel for East Asian Monsoon under the leadership of Prof. Shiyan Tao. The book would not have been possible without the efforts of the many reviewers. Besides the members of the Editorial Board of the World Scientific Series on Meteorology of East Asia who served as reviewers, the book benefited tremendously from the following individuals who provided critical reviews of individual chapters: Drs. Hanna Annamalai, Johnny Chan, Russ Elsberry, Bill Frank, Bob Haney, Harry Hendon, Brian Hoskins, Dick Johnson, T. N. Krishnamurti, Bill Kuo, Bill Kyle, Mark Lander, Peggy LeMone, Jerry Meehl, Takio Murakami, Julia Slingo, Wei-Kuo Tao, Mingfang Ting, Chuck Wash, and Song Yang. The technical editing was performed by Ms. Hway-Jen Chen. This work was supported in part by the National Science Foundation under Grant ATM-0101135, the National Oceanic and Atmospheric Administration under Grant NA01AANRG0011, and the Office of Naval Research Marine Meteorology Program.

\author{
Chih-Pei Chang \\ Naval Postgraduate School \\ Monterey, California
}




\section{CONTENTS}

Preface

\section{East Asian Summer and Winter Monsoon}

1. Seasonal March of the East-Asian Summer Monsoon

Yihui DING

2. The East Asia Winter Monsoon

Johnny CHAN and Chongyin LI

3. Maritime Continent Monsoon: Annual Cycle and Boreal Winter Variability C.-P. CHANG, Patrick A. HARR, John McBRIDE, and Huang-Hsiung HSU

\section{Interannual Variations}

4. Interannual Variability, Global Teleconnection, and Potential Predictability Associated with the Asian Summer Monsoon

William K.-M. LAU, Kyu-Myong KIM, and June-Yi LEE

5. East Asian Monsoon - ENSO Interactions

Bin WANG and Tim $\mathrm{LI}$

6. Climate Variations of the Summer Monsoon over China Ronghui HUANG, Gang HUANG, and Zhigang WEI

\section{General Circulation Modeling}

7. Simulations by a GFDL GCM of ENSO-Related Variability of the Coupled Atmosphere-Ocean System in the East Asian Monsoon Region Ngar-Cheung LAU, Mary Jo NATH, and Hailan WANG

8. Current Status of AGCM Monsoon Simulations In-Sik $K A N G$ 


\section{Synoptic and Mesoscale Processes}

10. Research on the Phenomena of Meiyu during the Past Quarter Century:

An Overview

George Tai-Jen CHEN

11. Large- and Mesoscale Features of Meiyu-Baiu Front Associated with Intense Rainfalls Kozo NINOMIYA

12. Oceanic East Asian Monsoon Convection: Results from the 1998 SCSMEX Richard H. JOHNSON, Paul E. CIESIELSKI, and Thomas D. KEENAN

\section{Interactions with Other Circulations}

13. Monsoon-Related Tropical Cyclones in East Asia Russell L. ELSBERRY

14. Formation of the Summertime Subtropical Anticyclones

Guoxiong WU, Yimin LIU, and Ping LIU

15. Maintenance and Seasonal Transitions of the Stationary Waves during East Asian Monsoon

Mingfang TING and Renu JOSEPH 